УДК 336.71

JEL Classification: F6, G21

TATAР М. C. ${ }^{1}$, РИКОВА А. O. ${ }^{2}$

\title{
ВПЛИВ ІНОЗЕМНОГО КАПІТАЛУ НА БАНКІВСЬКУ СИСТЕМУ УКРАЇНИ В УМОВАХ ГЛОБАЛІЗАЦЇ̈
}

DOI: $10.32620 /$ cher.2019.4.10

\begin{abstract}
Постановка проблеми. Сучасні глобалізаційні та інтеграційні процеси, впровадження новітніх інформаційних технологій, посилення конкуренції в банківському секторі, збільшення частки іноземного банківського капіталу, відсутність всебічної нормативно-правової регламентації банківської діяльності, недостатня розвиненість українских фінансових ринків, напружена криміногенна обстановка в країні й зростання економічної злочинності зумовлюють появу нових викликів і загроз фінансовій безпеці банківського сектору загалом і окремих банків зокрема. В свою чергу, ефективне функціонування банківської системи неможливі без дотримання високого рівня фінансової безпеки кожного окремого банку. Метою сmammi $\epsilon$ поглиблення теоретико-методологічних засад оцінювання фінансової безпеки комерційного банку й розробка практичних рекомендацій 3 підвищення іiі рівня. Предмет дослідження - теоретико-методологічні засади та практичні аспекти аналізу й оцінювання рівня фінансової безпеки банку. Методи, використані в дослідженні: логічно-змістовний метод, метод порівняння, метод аналізу і синтезу, метод експертних оцінок, метод коефіцієнтів, інтегральний метод тощо. Гіпотеза дослідження. Дослідження поточного стану фінансової безпеки банку слід проводити в декілька етапів: анкетування типових (зовнішніх та внутрішніх) загроз фінансовій безпеці банку; експрес-аналіз рівня фінансової безпеки комерційного банку; розрахунок інтегрального показника рівня фінансової безпеки банку. Виклад основного матеріалу. Здійснено анкетування типових зовнішніх та внутрішніх загроз фінансовій безпеці банку, результати якого показали, що від зовнішніх загроз фінансовій безпеці досліджуваний банк захищений на $60 \%$ (9 балів 3 15 можливих), а від внутрішніх загроз на 100\% (15 балів 315 можливих). На другому етапі процесу дослідження стану фінансової безпеки здійснено експрес-аналіз фінансової безпеки, який засновано на методі коефіцієнтів і який включає чотири групи основних банківських показників: показники фінансової стійкості банку, показники ділової активності банку, показники ліквідності банку, показники ефективності діяльності банку. Результати експрес-діагностики фінансової безпеки показали, що у 2014-2015 pр. у банка рівень фінансової безпеки був низьким, а в 2016-2018 рр. вже достатнім. Крім того, розраховано інтегральний показник фінансової безпеки банку, що включає такі показники: фінансово-економічні нормативи, показники доларизації кредитів і депозитів, показники ефективності банківської діяльності (ROA, ROE), показники прибутковості тощо. Отримані інтегральні показники рівня фінансової безпеки показали, що найвищий рівень фінансової безпеки був у 2016 р., а у 2018 р. він знизився майже вдвічі. Також запропоновано заходи з підвищення різних складових фінансової безпеки банку, практична реалізація яких дозволить підвищити ефективність управління фінансовою безпекою банківської установи. Оригінальність та практичне значення дослідження полягають в розробленні підходу до оцінювання фінансової безпеки комерційного банку і його реалізація на прикладі ПАТ«Райффайзен банк Аваль». Висновки дослідження. Запропоновано підхід до оцінювання рівня фінансової безпеки, що передбачає здійснення оцінювання в декілька етапів, а саме анкетування зовнішніх та внутрішніх загроз фінансовій безпеці банку, експрес-аналіз рівня фінансової безпеки комерційного банку та розрахунок інтегрального показника рівня фінансової без-
\end{abstract}

${ }^{1}$ Татар Марина Сергіївна, канд. екон. наук, доцент кафедры «Фінанси», Національний аерокосмічний університет ім. М.С. Жуковського «Харківський авіаційний інститут», м. Харків, Україна.

Tatar Maryna, Ph.D. in Economics, Associate professor of the Finance Department, National Aerospase University «Kharkiv Aviation Institute», Kharkiv, Ukraine.

ORCID ID: 0000-0002-1111-7103

e-mail: marina.sergeevna.tatar@gmail.com

2 Рикова Анастасія Олександрівна, магістрант спеціальності «Фінанси, банківська справа та страхування», Національний аерокосмічний університет ім. М. С. Жуковського «Харківський авіаційний інститут», м. Харків, Україна.

Rykova Anastasya, Master's degree of Finance, Banking and Insurance Specialty of the National Aerospase University «Kharkiv Aviation Institute», Kharkiv, Ukraine.

ORCID ID: 0000-0002-8845-2874

e-mail: agen.r.n@gmail.com 
пеки банку, що дасть можливість всебічно, комплексно оцінити рівень фінансової безпеки банку. Також запропоновано заходи з підвищення різних складових фінансової безпеки банку, практична реалізація яких дозволить підвищити ефективність управління фінансовою безпекою банківської установи. У межах подальшого дослідження планується оцінити ефективність запропонованих заходів з підвищення рівня фінансової безпеки банку.

\section{Ключові слова:}

заходи підвищення рівня фінансової безпеки, комерційний банк, оцінювання, управління, фінансова безпека.

\section{BANK FINANCIAL SECURITY EVALUATION PROCESS}

Formulation of the problem. Modern globalization and integration processes, introduction of the latest information technologies, competition in the banking sector, increasing of foreign banking capital share, lack of comprehensive legal regulation of banking activities, lack of development of Ukrainian financial markets, tense criminal challenges lead to new threats to financial security of the banking sector in general and of individual banks in particular. In turn, the efficient functioning of the banking system is impossible without maintaining high level of financial security of each commercial bank. The aim of the research is deepening the theoretical and methodological foundations of commercial bank financial security assessing and to development practical recommendations for improving its level. The subject of the research is theoretical and methodological principles and practical aspects of analysis and assessment of bank financial security level. The methods of the research: logical and meaningful method, method of comparison, method of analysis and synthesis, method of expert estimation, method of coefficients, integral method, etc. The hypothesis of the research. The investigation of the current state of a bank's financial security should be conducted in several stages: questioning of typical (external and internal) threats to the bank's financial security; express analysis of commercial bank financial security level; calculation of the integral index of bank financial security level. The statement of basic materials. The survey conducted typical external and internal threats to bank financial security, the results of which showed that the investigated bank is protected from external threats to financial security by $60 \%$ ( 9 points out of 15 possible) and from internal threats by $100 \%$ (15 points out of 15 possible). In the second stage of the process of financial security research, express analysis of financial security was carried out on the bases of the coefficients method, which includes four groups of basic banking indicators: bank financial stability indicators, bank business activity indicators, bank liquidity indicators, efficiency of bank activity indicators. The results of the rapid financial security diagnostics showed that in 2014-2015 the bank had low level of financial security, and in 20162018 it was sufficient. In addition, the integral financial security index of the bank is calculated, including the following indicators: financial and economic standards, credit and deposit dollarization, banking performance (ROA, ROE), profitability indicators and others. Integrated financial security indicators show that the highest level of financial security was in 2016, and in 2018 it was sufficient. It also proposes measures to enhance various components of the bank's financial security, the practical implementation of which will improve the efficiency of managing of banking institution financial security. The originality and practical significance of the research is development an approach to assessing commercial bank financial security and implementation it on the example of Raiffeisen Bank Aval. Conclusions and perspectives of further research. The approach to the assessment of the financial security level is proposed, which involves carrying out the evaluation in several stages, namely, the questioning of external and internal threats to bank financial security, express analysis of the financial security level of a commercial bank and calculation of an integral indicator of bank financial security level, which makes possible to assess the bank financial security level. It also proposes measures to enhance various components of the bank's financial security, the practical implementation of which will improve the efficiency of managing of banking institution financial security. As part of the further study it is planned to evaluate the effectiveness of the proposed measures of bank financial security level increasing.

\section{Keywords:}

financial security measures, commercial bank, assessment, management, financial security.

\section{ПРОЦЕСС ОЦЕНКИ УРОВНЯ ФИНАНСОВОЙ БЕЗОПАСНОСТИ БАНКА}

Постановка проблемы. Современные глобализационные и интеграционные процессы, внедрение новейших информационных технологий, усиление конкуренции в банковском секторе, увеличение доли иностранного банковского капитала, отсутствие всесторонней нормативно-правовой регламентации банковской деятельности, недостаточная развитость украинских финансовых рынков, напряженная криминогенная обстановка в стране и рост экономической преступности обусловли- 
вают появление новых вызовов и угроз финансовой безопасности банковского сектора в целом и отдельных банков в частности. В свою очередь, эффективное функционирование банковской системы невозможны без соблюдения высокого уровня финансовой безопасности каждого отдельного банка. Целью статьи является углубление теоретико-методологических основ оценки финансовой безопасности коммерческого банка и разработка практических рекомендаций по повышению ее уровня. Предмет исследования - теоретико-методологические основы и практические аспекты анализа и оценки уровня финансовой безопасности банка. Meтоды, используемые в исследовании: логически-содержательный метод, метод сравнения, метод анализа и синтеза, метод экспертных оценок, метод коэффициентов, интегральный метод и др. Гипотеза исследования. Исследование текущего состояния финансовой безопасности банка следует проводить в несколько этапов: анкетирование типовых (внешних и внутренних) угроз финансовой безопасности банка; экспресс-анализ уровня финансовой безопасности коммерческого банка; расчет интегрального показателя уровня финансовой безопасности банка. Изложение основного материала. Осуществлено анкетирование типичных внешних и внутренних угроз финансовой безопасности банка, результаты которого показали, что от внешних угроз финансовой безопасности исследуемый банк защищен на $60 \%$ (9 баллов из 15 возможных), а от внутренних угроз на 100\% (15 баллов из 15 возможных). На втором этапе процесса исследования состояния финансовой безопасности осуществлен экспресс-анализ финансовой безопасности, основанный на методе коэффициентов и включающий четыре группы основных банковских показателей: показатели финансовой устойчивости банка, показатели деловой активности банка, показатели ликвидности банка, показатели эффективности деятельности банка. Результаты экспресс-диагностики финансовой безопасности показали, что в 2014-2015 гг. у банка уровень финансовой безопасности был низким, а в 2016-2018 гг. уже достаточным. Кроме того, рассчитан интегральный показатель финансовой безопасности банка, включающий такие показатели: финансовоэкономические нормативы, показатели долларизации кредитов и депозитов, показатели эффективности банковской деятельности (ROA, ROE), показатели прибыльности и т.д. Полученные интегральные показатели уровня финансовой безопасности показали, что высокий уровень финансовой безопасности был в 2016, а в 2018 он снизился почти вдвое. Также предложены меры по повышению различных составляющих финансовой безопасности банка, практическая реализация которых позволит повысить эффективность управления финансовой безопасностью банковского учреждения. Оригинальность и практическое значение исследования заключаются в разработке подхода к оценке финансовой безопасности коммерческого банка и его реализация на примере $\mathrm{AO}$ «Райффайзен банк Аваль». Выводы исследования. Предложен подход к оценке уровня финансовой безопасности, который предусматривает осуществление оценки в несколько этапов, а именно анкетирование внешних и внутренних угроз финансовой безопасности банка, экспресс-анализ уровня финансовой безопасности коммерческого банка и расчет интегрального показателя уровня финансовой безопасности банка, что позволит всесторонне, комплексно оценить уровень финансовой безопасности банка. Также предложены меры по повышению различных составляющих финансовой безопасности банка, практическая реализация которых позволит повысить эффективность управления финансовой безопасностью банковского учреждения. В рамках дальнейшего исследования планируется оценить эффективность предложенных мер по повышению уровня финансовой безопасности банка.

\section{Ключевые слова:}

меры по повышению уровня финансовой безопасности, коммерческий банк, оценка, управление, финансовая безопасность.

Постановка проблеми. Сучасні глобалізаційні та інтеграційні процеси, впровадження новітніх інформаційних технологій, посилення конкуренції в банківському сектоpi, збільшення частки іноземного банківського капіталу, відсутність всебічної нормативно-правової регламентації банківської діяльності, недостатня розвиненість українских фінансових ринків, напружена криміногенна обстановка в країні й зростання економічної злочинності зумовлюють появу нових викликів і загроз фінансовій безпеці банківського сектору загалом і окремих банків зокрема. В свою чергу, ефективне функціонування банківської системи неможливі без дотримання високого рівня фінансової безпеки кожного окремого банку.

Аналіз останніх досліджень i публікацій. Проблематикою фінансової безпеки банківського сектору і окремих банків займались такі вітчизняні та зарубіжні вчені як Д. Алєксєєва, О. Барановський, І. Бланк, Т. Болгар, Р. Вовченко, Р. Гриценко, М. Єрмошенко, Я. Жарій, М. Зубок, О. Кириченко, В. 
Коваленко, О. Колодізєв, В. Краліч, І. Крупка, В. Левицький, О. Пластун, О. Терещенко, С. Яременко тощо. У працях вчених досліджувались сутність і складові, загрози фінансовій безпеці банків, методики оцінювання іiі рівня, передумови формування й організації функціонування системи іiі забезпечення тощо. Однак, потребує удосконалення процес управління фінансовою безпекою банку.

Метою статті є поглиблення теоретико-методологічних засад оцінювання фінансової безпеки комерційного банку й розробка практичних рекомендацій 3 підвищення іiі рівня.

Виклад основного матеріалу дослідження. Дослідження поточного стану фінансової безпеки банку пропонується проводити в декілька етапів:

- анкетування типових (зовнішніх та внутрішніх) загроз фінансовій безпеці банку;

- експрес-аналіз рівня фінансової безпеки комерційного банку;

- розрахунок інтегрального показника рівня фінансової безпеки банку.

У банківській практиці одним з якісних методів, що використовується у процесі діагностики поточного стану фінансової без- пеки банку, є анкетування [1]. Анкети формуються на основі переліку внутрішніх і зовнішніх загроз як критеріїв оцінки рівня фінансової безпеки банку.

До зовнішніх відносять загрози, які $\epsilon$ результатом впливу середовища навколо банків: законодавча і нормативна база, вимоги та діяльність регулятивних і наглядових органів, економічна кон'юнктура у країні й світі, конкуренти тощо. Для оцінки захищеності банку від зовнішніх загроз необхідно заповнити й розглянути відповідну анкету, обрати варіанти відповіді на поставлене питання «Банк захищений?» та кожному з наведених в анкеті видів загроз виставити бали 0 або 1. Щоб сумарна оцінка захищеності банку від зовнішніх загроз (ЗФБ) була адекватною, розгляд анкет здійснюється провідними фахівцями банку, що володіють матеріалами нормативно-законодавчої бази та ознайомлені 3 ключовими проблемними питаннями світового та вітчизняного ринків банківських послуг.

Анкета для оцінки захищеності банку від зовнішніх загроз була заповнена провідним спеціалістом ПАТ«Райффайзен банк Аваль». Отримані результати наведено в табл. 1.

Т а б ли ц я 1

Анкета для оцінки захищеності ПАТ«Райффайзен банк Аваль» від зовнішніх загроз

\begin{tabular}{|c|c|c|}
\hline Ч.Ч. & Види загроз & $\begin{array}{l}\text { Банк захищений? } \\
(\mathrm{TAK}=1 ; \mathrm{HI}=0)\end{array}$ \\
\hline 1 & Несприятлива загальносвітова економічна ситуація & 0 \\
\hline 2 & Кризові явища в країні & 0 \\
\hline 3 & Недосконалість законодавчої бази & 0 \\
\hline 4 & Зміни в політиці та нормативних актах НБУ & 0 \\
\hline 5 & Високий рівень інфляції та інфляційні очікування & 0 \\
\hline 6 & Нестійкість курсу національної валюти & 0 \\
\hline 7 & Постійний вплив ринкових ризиків & 1 \\
\hline 8 & Нерозвиненість фондового ринку країни & 1 \\
\hline 9 & Низький рівень інвестиційної активності & 1 \\
\hline 10 & Недосконала система страхування депозитів & 1 \\
\hline 11 & Низький рівень кредитоспроможності позичальників & 1 \\
\hline 12 & Невиконання клієнтами зобов'язань перед банком & 1 \\
\hline 13 & Недобросовісна конкуренція на ринку банківських послуг & 1 \\
\hline 14 & Прихід на ринок банківських послуг нових сильних гравців & 1 \\
\hline \multirow[t]{2}{*}{15} & Навмисні протиправні дії з боку клієнтів & 1 \\
\hline & УСЬОГО БАЛІВ $(0 \leq 3 Ф Б ~ \leq 15)$ & 9 \\
\hline
\end{tabular}

Джерело: розроблено авторами на підставі [1]

Внутрішні загрози генеруються самими банками, тому система фінансової безпеки має бути інтегрована в загальну систему управління банком, що дозволяє ухвалювати своєчасні й обгрунтовані рішення, здійснювати постійний контроль за внутрішнім середо- вищем, запобігати прояву навмисних дій та створенню кризових ситуацій у банку.

Для оцінювання захищеності банку від внутрішніх загроз необхідно розглянути анкету, обрати варіант відповіді на поставлене питання «Характерно для банку?» та для 
кожного 3 наведених в анкеті видів загроз виставити бали 0 або 1. Для коректності сумарної оцінки захищеності банку від внутрішніх загроз (ВФБ) слід користуватись фінансовою звітністю банку за попередні періоди, поточними показниками за різними напрямами діяльності банку, а також резуль- татами дій внутрішнього середовища, особливо тих, що спричиняють прояв наведених загроз. Анкета для оцінки захищеності банку від внутрішніх загроз також була заповнена провідним спеціалістом ПАТ«Райффайзен банк Аваль». Отримані результати наведено в табл. 2.

Т а б ли ц я 2

Анкета для оцінки захищеності ПАТ«Райффайзен банк Аваль» від внутрішніх загроз

\begin{tabular}{|c|l|c|}
\hline Ч.ч. & \multicolumn{1}{|c|}{ Види загроз } & $\begin{array}{c}\text { Банк захищений? } \\
\text { (ТАК }=1 ; \text { НI }=0)\end{array}$ \\
\hline 1 & Повна залежність від інсайдерів & 1 \\
\hline 2 & Порушення банком діючого законодавства і нормативів & 1 \\
\hline 3 & Порушення банком договірних відносин & 1 \\
\hline 4 & Помилки в стратегії та системі планування банку & 1 \\
\hline 5 & Неефективна система фінансового менеджменту банку & 1 \\
\hline 6 & Неякісна система управління ризиками & 1 \\
\hline 7 & Низький рівень капіталізації банку & 1 \\
\hline 8 & Недостатня ліквідність банку & 1 \\
\hline 9 & Низька якість банківських активів & 1 \\
\hline 10 & Ризикова та незважена кредитна діяльність & 1 \\
\hline 11 & Недостатня диверсифікація банківських операцій & 1 \\
\hline 12 & Недосконала цінова політика банку & 1 \\
\hline 13 & Нерозвинена маркетингова діяльність банку & 1 \\
\hline 15 & Наявність зловживань або протиправних дій в банку & 1 \\
\hline & Наявність каналів витоку банківської інформації & 1 \\
\hline
\end{tabular}

Джерело: розроблено авторами на підставі [1]

Отже, від зовнішніх загроз фінансовій безпеці банк захищений на $60 \%$ (9 балів з 15 можливих), а від внутрішніх загроз на 100\% (15 балів 315 можливих).

Відповідно до кількості набраних балів банк отримує попередню оцінку рівня фінансової безпеки (високий, достатній, низький, критичний) за кожним 3 видів загроз (зовнішніх та внутрішніх). Якщо кожна з отриманих оцінок (одна 3 них) наближується до критичного рівня, необхідно оперативно про- вести комплексний аналіз фінансового стану банку, що дозволить оцінити реальний ступінь загрози фінансовій безпеці банку, виявити основні проблемні питання та застосувати заходи щодо їх усунення.

Тому на другому етапі процесу дослідження стану фінансової безпеки розглянуто методику спрощеного експрес-аналізу фінансової безпеки, який засновано на методі коефіцієнтів і який включає чотири групи основних банківських показників (табл. 3).

Т а б ли ц я 3

Експрес-аналіз фінансової безпеки банку

\begin{tabular}{|c|c|c|c|c|}
\hline Ч.ч. & Показник & Розрахунок & Умови & Бали \\
\hline 1 & 2 & 3 & 4 & 5 \\
\hline \multicolumn{5}{|c|}{ Блок 1. Аналіз фінансової стійкості банку } \\
\hline \multirow[t]{3}{*}{1.1} & \multirow{3}{*}{$\begin{array}{l}\text { Рівень капіталізації банку, } \\
\text { К11 }\end{array}$} & \multirow{3}{*}{$\begin{array}{l}\text { Регулятивний капітал } \\
\text { Норматив Н1 }\end{array}$} & $\mathrm{K} 11<1$ & 1 \\
\hline & & & $1 \leq \mathrm{K} 11 \leq 5$ & 2 \\
\hline & & & K11 > 5 & 3 \\
\hline \multirow[t]{3}{*}{1.2} & \multirow{3}{*}{$\begin{array}{l}\text { Коефіцієнт співвідношен- } \\
\text { ня регулятивного капіталу } \\
\text { до сукупних активів, К12 }\end{array}$} & \multirow{3}{*}{$\begin{array}{l}\text { Регулятивний капітал } \\
\text { Сукупні активи }\end{array}$} & $\mathrm{K} 12<0,09$ & 1 \\
\hline & & & $\mathrm{K} 12>0,12$ & 2 \\
\hline & & & $0,09 \leq \mathrm{K} 12 \leq 0,12$ & 3 \\
\hline \multirow[t]{3}{*}{1.3} & \multirow[t]{3}{*}{ Коефіцієнт надійності, К13 } & \multirow{3}{*}{$\frac{\text { Власний капітал }}{\text { Зобов'язання }}$} & $\mathrm{K} 13<0,1$ & 1 \\
\hline & & & $\mathrm{K} 13>0,15$ & 2 \\
\hline & & & $0,1 \leq \mathrm{K} 13 \leq 0,15$ & 3 \\
\hline \multirow[t]{3}{*}{1.4} & \multirow{3}{*}{$\begin{array}{l}\text { Мультиплікатор акціонер- } \\
\text { ного } \\
\text { капіталу, К14 }\end{array}$} & \multirow{3}{*}{$\begin{array}{l}\text { Ділові активи } \\
\text { Статутний фонд }\end{array}$} & K14 > 15 & 1 \\
\hline & & & K14 $<12$ & 2 \\
\hline & & & $12 \leq \mathrm{K} 14 \leq 15$ & 3 \\
\hline
\end{tabular}


Продовження табл. 3

\begin{tabular}{|c|c|c|c|c|}
\hline 1 & 2 & 3 & 4 & $\frac{10}{5}$ \\
\hline \multirow[t]{3}{*}{1.5} & \multirow{3}{*}{$\begin{array}{l}\text { Коефіцієнт захищеності } \\
\text { власного капіталу, К15 }\end{array}$} & \multirow{3}{*}{$\frac{\text { Основні засоби }}{\text { Власний капітал }}$} & $\mathrm{K} 15>0,5$ & 1 \\
\hline & & & $\mathrm{K} 15<0,3$ & 2 \\
\hline & & & $0,3 \leq \mathrm{K} 15 \leq 0,5$ & 3 \\
\hline \multirow[t]{3}{*}{1.6} & \multirow{3}{*}{$\begin{array}{l}\text { Коефіцієнт знецінення } \\
\text { активів } \\
\text { банку, К16 }\end{array}$} & \multirow{3}{*}{$\begin{array}{l}\text { Резерви за активами банку } \\
\text { Сукупні активи }\end{array}$} & $\mathrm{K} 16>0,2$ & 1 \\
\hline & & & $0,1 \leq \mathrm{K} 16 \leq 0,2$ & 2 \\
\hline & & & $\mathrm{K} 16<0,1$ & 3 \\
\hline \multicolumn{5}{|c|}{ Блок 2. Аналіз ділової активності банку } \\
\hline \multirow[t]{3}{*}{2.1} & \multirow{3}{*}{$\begin{array}{l}\text { Коефіцієнт активності за- } \\
\text { лучення коштів юридич- } \\
\text { них і фізичних осіб, К21 }\end{array}$} & \multirow{3}{*}{$\frac{\text { Кошти клієнтів }}{\text { Зобов'язання }}$} & $\mathrm{K} 21<0,65$ & 1 \\
\hline & & & $\mathrm{K} 21>0,75$ & 2 \\
\hline & & & $0,65 \leq \mathrm{K} 21 \leq 0,75$ & 3 \\
\hline \multirow[t]{3}{*}{2.2} & \multirow{3}{*}{$\begin{array}{l}\text { Коефіцієнт активності за- } \\
\text { лучення коштів банків, } \\
\text { К22 }\end{array}$} & \multirow{3}{*}{$\frac{\text { Кошти банків }}{\text { Зобов'язання }}$} & $\mathrm{K} 22>0,3$ & 1 \\
\hline & & & $\mathrm{K} 22<0,15$ & 2 \\
\hline & & & $0,15 \leq \mathrm{K} 22 \leq 0,3$ & 3 \\
\hline \multirow[t]{3}{*}{2.3} & \multirow{3}{*}{$\begin{array}{l}\text { Коефіцієнт інвестицій у } \\
\text { кредитний портфель, К23 }\end{array}$} & \multirow{3}{*}{$\begin{array}{l}\text { Кредитний портфель } \\
\text { Сукупні активи }\end{array}$} & К $23<0,6$ або $>0,8$ & 1 \\
\hline & & & $0,7<\mathrm{K} 23 \leq 0,8$ & 2 \\
\hline & & & $0,6 \leq \mathrm{K} 23 \leq 0,7$ & 3 \\
\hline \multirow[t]{3}{*}{2.4} & \multirow{3}{*}{$\begin{array}{l}\text { Коефіцієнт інвестицій у } \\
\text { ЦП та спільну господарсь- } \\
\text { ку діяльність, К24 }\end{array}$} & \multirow{3}{*}{$\begin{array}{l}\text { Інвестиційний портфель } \\
\text { Сукупні активи }\end{array}$} & $\mathrm{K} 24<0,2$ або $>0,4$ & 1 \\
\hline & & & $0,3<\mathrm{K} 24 \leq 0,4$ & 2 \\
\hline & & & $0,2 \leq \mathrm{K} 24 \leq 0,3$ & 3 \\
\hline \multicolumn{5}{|c|}{ Блок 3. Аналіз ліквідності банку } \\
\hline \multirow[t]{3}{*}{3.1} & Коефіцієнт висо- & Високоліквідні активи & $\mathrm{K} 31<0,15$ & 1 \\
\hline & коліквідних активів, К31 & Ділові активи & $\mathrm{K} 31>0,2$ & 2 \\
\hline & & & $0,15 \leq \mathrm{K} 31 \leq 0,2$ & 3 \\
\hline 3.2 & Коефіцієнт загальної & Ділові активи & $\mathrm{K} 32<1$ & 1 \\
\hline & ліквідності зобов'язань & Зобов'язання & $\mathrm{K} 32>1,2$ & 2 \\
\hline & банку, К32 & & $1 \leq \mathrm{K} 32 \leq 1,2$ & 3 \\
\hline 3.3 & Коефіцієнт ліквідного & Кредитний портфель & $\mathrm{K} 33<1,1$ & 1 \\
\hline & співвідношення наданих & Кошти клієнтів & $\mathrm{K} 33>1,5$ & 2 \\
\hline & $\begin{array}{l}\text { кредитів і залучених депо- } \\
\text { зитів, К } 33\end{array}$ & & $1,1 \leq \mathrm{K} 33 \leq 1,5$ & 3 \\
\hline 3.4 & Коефіцієнт генеральної & Високоліквідні активи + О3 & $\mathrm{K} 34<0,2$ & 1 \\
\hline & ліквідності зобов'язань, & Зобов’язання & $\mathrm{K} 34>0,3$ & 2 \\
\hline & К34 & & $0,2 \leq \mathrm{K} 34 \leq 0,3$ & 3 \\
\hline & Блок & . Аналіз ефективності діяльно & гі банку & \\
\hline 4.1 & Загальний рівень прибут- & Прибуток до оподаткування & $\mathrm{K} 41<0,05$ & 1 \\
\hline & ковості, К41 & Доходи банку & $0,05 \leq \mathrm{K} 41<0,1$ & 2 \\
\hline & & & $\mathrm{K} 41 \geq 0,1$ & 3 \\
\hline 4.2 & Окупність витрат дохода- & Доходи банку & $\mathrm{K} 42 \leq 1$ & 1 \\
\hline & ми, К42 & Витрати банку & $1<\mathrm{K} 42 \leq 1,1$ & 2 \\
\hline & & & $\mathrm{K} 42>1,1$ & 3 \\
\hline 4.3 & Рентабельність капіталу, & Чистий прибуток & $\mathrm{ROE}<0,1$ & 1 \\
\hline & & Власний капітал & $0,1 \leq \mathrm{ROE}<0,15$ & 2 \\
\hline & & & $\mathrm{ROE} \geq 0,15$ & 3 \\
\hline 4.4 & Рентабельність & Чистий прибуток & $\mathrm{ROA}<0,01$ & 1 \\
\hline & ROA & Сукупні активи & $0,01 \leq \mathrm{ROA}<0,02$ & 2 \\
\hline & & & $\mathrm{ROA} \geq 0,02$ & 3 \\
\hline 4.5 & Чиста процентна маржа, & Процентні (доходи - витра- & ЧПМ $<0,05$ & 1 \\
\hline & ЧПМ & $\underline{\text { ти) }}$ & $0,05 \leq$ ЧПМ $\leq 0,07$ & 2 \\
\hline & & Ділові активи & ЧПМ > 0,07 & 3 \\
\hline 4.6 & Коефіцієнт резервування & Резерви під знецінення ак- & $K 46 \geq 0,3$ & 1 \\
\hline & під знецінення активів і & тивів і пасивів & $0,1 \leq \mathrm{K} 46<0,3$ & 2 \\
\hline & пасивів, К46 & Витрати банку & $\mathrm{K} 46<0,1$ & 3 \\
\hline
\end{tabular}

Джерело: розроблено авторами на підставі [1]

Аналіз фінансової стійкості банку здійснюється 3 використанням нормативів капіталу, що контролюються НБУ, та інших показників, що базуються на аналізі співвідношень між різними групами активів, зобов'язань i власного капіталу. Визначені показники дозволяють відстежити дотримання нормативних вимог та оцінити «капіталь- 
ну силу» банку щодо залучення ресурсів, формування активів, покриття ризиків та протистояння внутрішнім і зовнішнім загрозам фінансовій безпеці.

Ділова активність банку дає можливість охарактеризувати спроможність банку залучати кошти та ефективно їх розміщувати. Перші два показники дозволяють розкрити можливості і спрямованість банку щодо залучення ресурсів, два інші показники свідчать про їх використання під час формування активів. Оскільки банки в основному працюють 3 чужими грошима, рівень ділової активності щодо залучення зовнішніх джерел фінансування їх діяльності має бути високим. 3 іншого боку, слід ураховувати, що надмірна ділова активність банку може погіршити фінансову стійкість банку та негативно вплинути на його фінансовий стан, особливо у разі високої залежності банку від ресурсів міжбанківського ринку.

Ліквідність банку дає можливість оцінити здатність банку виконувати свої зо- бов'язання перед клієнтами, кредиторами, інвесторами, акціонерами та іншими контрагентами в аналізованих періодах.

Ефективність діяльності банку дає можливість зробити висновки про раціональність структури активів і пасивів банку та рівень їх знецінення. Найбільш суттєвими показниками, що характеризують професіоналізм і злагодженість у роботі менеджерів $\epsilon$ показники рентабельності капіталу (ROE) та активів (ROA). Вони відображають рівень ефективності діяльності банку, його спроможність створювати прибуток, управляти ризиками та підтримувати фінансову безпеку на належному рівні.

Розраховані за кожним 3 чотирьох блоків аналізу сумарні фактичні бали дають можливість виявити основні проблеми та визначити поточний рівень фінансової безпеки банку $(20 \leq P Ф Б Б \leq 60)$.

Інтерпретація отриманих значень рівня фінансової безпеки банку наведена в табл. 4.

Т а б ли ц я 4

Інтерпретація отриманих значень рівня фінансової безпеки банку

\begin{tabular}{|c|c|}
\hline Значення & Інтерпретація \\
\hline Дорівнює 60 балів & $\begin{array}{l}\text { Рівень фінансової безпеки банку є високим. Банк можна вважати надійним за } \\
\text { всіма аспектами діяльності, він є стійким до змін, що відбуваються на ринку. } \\
\text { Із впливом зовнішніх та внутрішніх загроз на банківську безпеку банк у змозі } \\
\text { впоратись у поточній діяльності. }\end{array}$ \\
\hline Від 40 до 60 балів & $\begin{array}{l}\text { Рівень фінансової безпеки банку є достатнім. Залежно від того, до якої межі } \\
\text { інтервалу РФББ є ближчим, менеджменту банку необхідно приймати } \\
\text { відповідні рішення щодо усунення проблем та недопущення серйозного по- } \\
\text { гіршення рівня фінансової безпеки банку. }\end{array}$ \\
\hline Від 20 до 40 балів & $\begin{array}{l}\text { Рівень фінансової безпеки банку вважається низьким, банк має досить серйо- } \\
\text { зні фінансові проблеми з імовірним їх поглибленням, якщо показник набли- } \\
\text { жується до } 20 \text { балів. Керівництво та власники банку мають терміново вжити } \\
\text { заходів щодо фінансового оздоровлення банку, можливо й нестандартних, } \\
\text { для укріплення захисту від впливу загроз банківській безпеці. }\end{array}$ \\
\hline $\begin{array}{l}20 \text { балів упродовж } \\
\text { декількох років }\end{array}$ & $\begin{array}{l}\text { Коли упродовж декількох років рівень фінансової безпеки приблизно } 20 \text { балів } \\
\text { - це найскладніша ситуація, яка свідчить про багато проблем у діяльності } \\
\text { банку та про відсутність досконалої системи захисту від впливу зовнішніх і } \\
\text { внутрішніх загроз. } 3 \text { високою ймовірністю така установа швидко стане не- } \\
\text { платоспроможним банком, який буде ліквідовано. }\end{array}$ \\
\hline
\end{tabular}

Джерело: складено авторами на підставі [1]

Показник рівня фінансової безпеки банку слід розраховувати постійно з відстеженням тенденцій змін показника в різних часових інтервалах, що дасть можливість контролювати стан фінансової безпеки банку.

Отримані результати розрахунку показників для здійснення експрес-аналізу рівня фінансової безпеки ПАТ «Райффайзен банк Аваль» наведено в табл. 5.
Загальна сума балів за показниками рівня фінансової безпеки ПАТ«Райффайзен банк Аваль» представлена у табл. 6.

Інтерпретація рівня фінансової безпеки ПАТ«Райффайзен банк Аваль» представлено в табл. 7.

Надалі розрахуємо також інтегральний показник фінансової безпеки банку, що включає такі показники: 
Т а бли ц я 5

Результати розрахунку показників для здійснення експрес-аналізу рівня фінансової безпеки

\begin{tabular}{|c|c|c|c|c|c|}
\hline & & & & & \\
\hline \multirow{2}{*}{ Показник } & \multicolumn{5}{|c|}{ Значення за роками } \\
\hline & 2014 & 2015 & 2016 & 2017 & 2018 \\
\hline \multicolumn{6}{|c|}{ Блок 1. Аналіз фінансової стійкості банку } \\
\hline Рівень капіталізації банку, К11 & 1,1621 & 1,0000 & 1,0000 & 1,0000 & 1,0000 \\
\hline $\begin{array}{l}\text { Коефіцієнт співвідношення регулятивного капіталу } \\
\text { до сукупних активів, К12 }\end{array}$ & 0,0634 & 0,0624 & 0,2181 & 0,1682 & 0,1420 \\
\hline Коефіцієнт надійності, К13 & 0,0886 & 0,1102 & 0,1866 & 0,1930 & 0,1882 \\
\hline Мультиплікатор акціонерного капіталу, К14 & 15,3641 & 13,2800 & 11,3687 & 15,4104 & 14,4145 \\
\hline Коефіцієнт захищеності власного капіталу, К15 & 0,5344 & 0,4018 & 0,2187 & 0,1880 & 0,1995 \\
\hline Коефіцієнт знецінення активів банку, К16 & 0,0010 & 0,0005 & 0,0009 & 0,0012 & 0,0022 \\
\hline \multicolumn{6}{|c|}{ Блок 2. Аналіз ділової активності банку } \\
\hline $\begin{array}{l}\text { Коефіцієнт активності залучення коштів юридичних } \\
\text { і фізичних осіб, К21 }\end{array}$ & 0,6823 & 0,8265 & 0,9123 & 0,9305 & 0,9396 \\
\hline Коефіцієнт активності залучення коштів банків, К22 & 0,1949 & 0,1168 & 0,0682 & 0,0451 & 0,0185 \\
\hline Коефіцієнт інвестицій у кредитний портфель, К23 & 0,6519 & 0,4923 & 0,4868 & 0,5573 & 0,6412 \\
\hline $\begin{array}{l}\text { Коефіцієнт інвестицій у ЦП та спільну господарську } \\
\text { діяльність, К } 24\end{array}$ & 0,0993 & 0,0559 & 0,0589 & 0,0884 & 0,0468 \\
\hline \multicolumn{6}{|c|}{ Блок 3. Аналіз ліквідності банку } \\
\hline Коефіцієнт високоліквідних активів, К31 & 0,1410 & 0,2348 & 0,1794 & 0,1537 & 0,1404 \\
\hline Коефіцієнт загальної ліквідності зобов'язань банку, К32 & 1,0886 & 1,1102 & 1,1866 & 1,1930 & 1,1882 \\
\hline $\begin{array}{l}\text { Коефіцієнт ліквідного співвідношення наданих кре- } \\
\text { дитів і залучених депозитів, К33 }\end{array}$ & 1,0401 & 0,6613 & 0,6331 & 0,7145 & 0,8108 \\
\hline Коефіцієнт генеральної ліквідності зобов'язань, К34 & 0,2009 & 0,3050 & 0,2537 & 0,2196 & 0,2044 \\
\hline \multicolumn{6}{|c|}{ Блок 4. Аналіз ефективності діяльності банку } \\
\hline Загальний рівень прибутковості, К41 & $-1,2216$ & $-0,9456$ & 0,0547 & 0,0874 & 0,1564 \\
\hline Окупність витрат доходами, К42 & 0,9525 & 0,8753 & 1,4542 & 1,4212 & 1,3752 \\
\hline Рентабельність капіталу, ROE & $-1,0500$ & $-0,3570$ & 0,7140 & 0,7200 & 0,6730 \\
\hline Рентабельність активів, ROA & $-0,0900$ & $-0,0360$ & 0,0670 & 0,0860 & 0,0740 \\
\hline Чиста процентна маржа, ЧПМ & 0,0881 & 0,0766 & 0,0844 & 0,0721 & 0,0926 \\
\hline $\begin{array}{l}\text { Коефіцієнт резервування під знецінення активів і } \\
\text { пасивів, К } 46\end{array}$ & 0,2877 & 0,2468 & 0,2763 & 0,1546 & 0,0985 \\
\hline
\end{tabular}

Джерело: розраховано авторами на підставі $[1,3]$

Т а б лиц я 6

Загальна сума балів за показниками рівня фінансової безпеки

\begin{tabular}{|l|c|c|c|c|c|}
\hline \multirow{2}{*}{ Показник } & \multicolumn{5}{|c|}{ Значення за роками } \\
\cline { 2 - 6 } & 2014 & 2015 & 2016 & 2017 & 2018 \\
\hline 1. Аналіз фінансової стійкості банку & 9 & 15 & 13 & 12 & 14 \\
\hline 2. Аналіз ділової активності банку & 10 & 6 & 6 & 6 & 8 \\
\hline 3. Аналіз ліквідності банку & 8 & 8 & 10 & 10 & 8 \\
\hline 4. Аналіз ефективності діяльності банку & 9 & 9 & 16 & 16 & 18 \\
\hline Загальна сума балів & 36 & 38 & 45 & 44 & 48 \\
\hline
\end{tabular}

Джерело: розраховано авторами на підставі $[1,3]$

Т а б ли ц я 7

Інтерпретація рівня фінансової безпеки ПАТ «Райффайзен банк Аваль»

\begin{tabular}{|c|c|}
\hline Роки & Рівень фінансової безпеки \\
\hline 2014-2015 & $\begin{array}{l}\text { Рівень фінансової безпеки банку вважається низьким, банк має досить серйозні фінансові } \\
\text { проблеми з імовірним їх поглибленням. Керівництво та власники банку мають терміново } \\
\text { вжити заходів щодо фінансового оздоровлення банку, можливо й нестандартних, для } \\
\text { укріплення захисту від впливу загроз банківській безпеці. }\end{array}$ \\
\hline 2016 & $\begin{array}{l}\text { Рівень фінансової безпеки банку є достатнім. Залежно від того, до якої межі інтервалу } \\
\text { рівень фінансової безпеки є ближчим, менеджменту банку необхідно приймати відповідні } \\
\text { рішення щодо усунення проблем та недопущення серйозного погіршення рівня фінансової } \\
\text { безпеки банку. }\end{array}$ \\
\hline
\end{tabular}


фінансово-економічні нормативи (зокрема, адекватність регулятивного капіталу, показник базових ліквідних активів і показники ліквідності тощо), показники доларизації кредитів і депозитів, показники ефективності банківської діяльності (ROA, $\mathrm{ROE})$, показники прибутковості тощо.
Отримані значення інтегральних показників рівня фінансової безпеки банку представлено у табл. 8. Значення інтегральних показників змінюються від 0 до 1, чим ближче до 1, тим вище рівень фінансової безпеки.

Інтегральний показник рівня фінансової безпеки банку

\begin{tabular}{|c|c|c|c|c|c|}
\hline \multirow{2}{*}{ Показник } & \multicolumn{5}{|c|}{ Значения за роками } \\
\cline { 2 - 6 } & 2014 & 2015 & 2016 & 2017 & 2018 \\
\hline H1 & 3004256 & 3344615 & 3325789 & 11220414 & 10480006 \\
\hline H2 & 7,64 & 8,26 & 108,58 & 23,8 & 19,04 \\
\hline H4 & 87,52 & 157,73 & 108,58 & 93,94 & 42,91 \\
\hline H5 & 52,51 & 157,73 & 54,29 & 93,94 & 52,51 \\
\hline H6 & 84,25 & 163,7 & 149,8 & 154,2 & 84,25 \\
\hline H7 & 14,48 & 18,19 & 4,7 & 5,72 & 10,13 \\
\hline H9 & 144,78 & 144,27 & 38,8 & 50,07 & 20,17 \\
\hline RОА & 0,19 & 0,18 & 0,07 & 0,11 & 0,37 \\
\hline RОЕ & $-0,09$ & $-0,036$ & 0,067 & 0,086 & 0,074 \\
\hline $\begin{array}{c}\text { Інтегральний показ- } \\
\text { ник рівня фінансової } \\
\text { безпеки банку }\end{array}$ & $-1,05$ & $-0,357$ & 0,714 & 0,72 & 0,673 \\
\hline
\end{tabular}

Джерело: розраховано авторами на підставі [3]

Таким чином, отримані інтегральні показники рівня фінансової безпеки показують, що найвищий рівень фінансової безпеки був у 2016 р., а у 2018 р. він знизився майже вдвічі, отже, слід запропонувати заходи 3 підвищення рівня фінансової безпеки.
На рівні ПАТ «Райффайзен банк Аваль» для забезпечення високого рівня фінансової безпеки необхідно запроваджувати заходи для управління окремими складовими фінансової безпеки (табл. 9).

Т а б ли ц я 9

Заходи з убезпечення ПАТ«Райффайзен банк Аваль», які приймаються на рівні банку

Управління

складовими

фінансової

Заходи з убезпечення ПАТ«Райффайзен банк Аваль», які приймаються на рівні банку

безпеки

\begin{tabular}{|l|l|}
\hline 1 & 2 \\
\hline & Отримання застави, корпоративних і особистих гарантій; встановлення лімітів ризику по- \\
& зичальника або іх групи; аналіз спроможності наявних і потенційних позичальників вико-
\end{tabular}

Управління кредитною безпекою нувати свої зобов'язання; зміна лімітів кредитування; встановлення лімітів кредитних повноважень; моніторинг кредитів в інтерактивному режимі, поточної вартості застави; щоденне визначення проблемних кредитів; блокування можливості відділення або менеджера, відповідального за конкретну кредитну програму, надавати нові кредити, якщо відсоток проблемних кредитів

Управління

валютною

безпекою

Управління відсотковою безпекою

Управління безпекою ліквідності
Щоденний моніторинг та аналіз відкритих позицій банку за валютами й дорогоцінними металами; щоденний контроль накопичених прибутків/збитків за операціями з валютою; стрес-тестування та розрахунок потенційних втрат внаслідок несприятливих і екстремальних коливань валютних курсів; встановлення відповідних лімітів як для кожної валюти окремо, так і для загальної відкритої валютної позиції; встановлення обмежень на накопичені прибутки/збитки за валютними операціями відкритої валютної позиції

Вимірювання чутливості до паралельного зсуву кривої дохідності за кожною валютою на один базисний пункт; оцінка впливу коливань ринкових ставок на відсотковий дохід банку Регулярне формування звіту про невідповідність між активами і пасивами за строками до погашення та дослідження відповідних розривів за часовими проміжками і поведінки продуктів без заздалегідь визначеного строку погашення (поточні рахунки клієнтів, кореспондентські рахунки банків), а також строкових продуктів, для яких можлива пролонгація в рамках звичайних ринкових умов 
Продовження табл. 9

\begin{tabular}{|c|c|}
\hline 1 & 2 \\
\hline $\begin{array}{c}\text { Управління } \\
\text { ціновою } \\
\text { безпекою }\end{array}$ & $\begin{array}{l}\text { Регулярне відстеження змін котирувань боргових цінних паперів (облігацій) у торговель- } \\
\text { ному портфелі банку, а на кожну звітну дату - переоцінка таких інструментів до їхньої } \\
\text { ринкової вартості; відстеження коливання ринкових процентних ставок та їхньої } \\
\text { відповідності котируванням цінних паперів; щоденний розрахунок чутливості торгової } \\
\text { позиції до змін ринкових котирувань (ставок), встановлення обмеження на накопичені } \\
\text { збитки за торговими операціями для лімітування прийнятного цінового ризику }\end{array}$ \\
\hline $\begin{array}{c}\text { Управління } \\
\text { ринковою } \\
\text { безпекою }\end{array}$ & $\begin{array}{l}\text { Аналіз чутливості, моніторинг позиції та метод оцінки ймовірних втрат, а також моніто- } \\
\text { ринг накопичених збитків; встановлення відповідних лімітів }\end{array}$ \\
\hline
\end{tabular}

Джерело: розроблено авторами на підставі [3]

Крім того, підвищенню рівня фінансової безпеки банку сприятиме впровадження в банку менеджменту якості, що спричинить розширення переліку банківських продуктів і послуг та підвищення їх якості, поліпшення корпоративного управління і підвищення задоволення потреб різних категорій клієнтів.

Висновки та перспективи подальших досліджень. Отже, запропонований підхід до оцінювання рівня фінансової безпеки передбачає здійснення оцінювання в декілька етапів: анкетування зовнішніх та внутрішніх загроз фінансовій безпеці банку; експрес-аналіз рівня фінансової безпеки комерційного банку та розрахунок інтегрального показника рівня фінансової безпеки банку, що дасть можливість всебічно, комплексно оцінити рівень фінансової безпеки банку. Також запропоновано заходи 3 підвищення різних складових фінансової безпеки банку. Практична реалізація запропонованих заходів дозволить підвищити ефективність управління фінансовою безпекою банківської установи. У межах подальшого дослідження планується оцінити ефективність запропонованих заходів 3 підвищення рівня фінансової безпеки банку.

\section{Література}

1. Жарій Я. В. Методичні підходи до оцінювання рівня фінансової безпеки ко- мерційного банку. Фінансові дослідження. 2016. №1. C. 130-137.

2. Вовченко Р. С. Чинники i загрози фінансовій безпеці банківського сектору національної економіки. Збірник наукових пращь «Фінансово-економічна діяльність: проблеми теорії та практики». 2013. № 1. С. 75-83.

3. Фінансова звітність ПАТ«Райффайзен банк Аваль» за 2014-2018 pр. Офіційний вебсайт ПАТ«Райффайзен банк Аваль». URL: https://www.aval.ua/ru (дата звернення $: 10.11 .2019)$

4. Офіційний веб-сайт Національного банку України. URL: https://bank.gov.ua_(дата звернення :10.11.2019)

\section{References}

1. Zhary Y. V. (2016) Methodical Approaches to Assessing the Financial Security Level of a Commercial Bank. Financial Research, 1, 130-137.

2. Vovchenko R.S. (2013) Factors and threats to the financial security of national economy banking sector. Collection of scientific papers "Financial and economic activities: problems of theory and practice", 1, 75-83.

3. Financial statements of Raiffeisen Bank Aval in 2014-2018 years. The official website of Raiffeisen Bank Aval. Retreived from: https://www.aval.ua/en

4. Official Website of the National Bank of Ukraine Retreived from: https://bank.gov.ua.

Стаття прийнята

до друку: 27.12.2019 p.

Бібліографічний опис для цитування :

Татар М. С. Процес оцінювання рівня фінансової безпеки банку / М. С. Татар, А. О. Рикова // Часопис економічних реформ. - 2019. - № 4 (36). - С. 76-85. 